\title{
Sosialisasi dan Implementasi Penanganan Transaksi dan Akad Syariah Pada Majlis Ta'lim An Nisa Jln Bakung 04 Kelurahan Lowokwaru Kota Malang
}

\author{
Muhammad Muwidha ${ }^{1}$, Himma $^{2}$, Basuki $^{3}$, Yusna $^{4}$ \\ ${ }_{1,2,3,4}$ Politeknik Negeri Malang \\ e-mail: ${ }^{1}$ muhammadmuwidha03@gmail.com
}

\begin{abstract}
Abstrak
Tujuan Kegiatan Pengabdian kepada Masayarakat (PkM) ini adalah dalam rangka memberikan penyuluhan, sosialisasi dan implementasi kepada masyarakat mengenai akad-akad transaksi usaha secara syariah kepada ibu-ibu anggota majlis ta'lim An-Nisa. Paada awalnya pelaksanaannya akan dilakukan di rumah Jln. Bakung 04 Lowokwaru Kota Malang. Karena masa pandemi akhirnya berdasarkan koodinasi tim PkM , Ketua Majlis Ta'lim An-Nisa dan Takmir Masjid Fadhilah, maka kegiatan dilaksanakan di masjid dengana mangambil jadwal setelah jamaah subuh pada hari Selasa tanggal 18 dan 25 Agustus 2020. Jam 5.00- 7.00. Peserta berjumlah 46 orang terdiri dari bapak dan ibu.

Pada saat pelaksanaan materi yang direncanakan telah disajikan dengan lancar. Materi ini dinilai penting karena untuk memulai berbisnis yang berlandaskan syariah maka jenis dan keabsyahan transaksi perlu dipahami dengan baik an benar. Bila transaksi sudah dipahami barulah memilih berbagai tawaran akad syariah dengan menyesuaikan kebutuhan dalam berbisnis.

Menurut perspektif Islam, hukum Islam diciptakan dan dilaksanakan secara menyeluruh tidak lain adalah bertujuan demi kemaslahatan dan kesejahteraan manisia di dunia dan akhirat. Untuk mencapai tujuan tersebut maka hukum Islam mempunyai beberapa prinsip yang mendasari terlaksananya tujuan tersebut, yaitu: 1) memberikan kemudahan dan meniadakan kesulitan, 2) menyedikitkan beban, dan 3) menempuh jalan pertahapan.

Temuan dan pengelaman dalam pelaksanaan PkM ini diharapkan menjadi fase lanjut untuk membangun kesadaran tentang menjadi umat islam yang kaffah. Tidak hanya tekun dalam ibadah kepada Allah (mahdhoh) tapi juga harus membangun muammalah yang lebih baik. Karena pada intinya islam justru ajaran banyak mengatur bagaimana mu'ammalah diamalkan dengan lebih masive. Islam adalah ajarah rahmat terciptanya kedamaian. Kedaaian bisa diciptakan jika masyarakat relatif telah sadar dan faham tentang taraf sejahtera dan ukuran sejahtera paling sederhana adalah kecukupan hidup dan ini pasti berbincang tentang jalan rizki serta ksejahteraan ekonomi.
\end{abstract}

Kata kunci-Sosialiasi, Implementasi, Transaki dan Akad Syariah

\section{PENDAHULUAN}

\subsection{Analisis Situasi}

Berbagai konsep yang telah disusun oleh para ahli mengenai bisnis syariah, hingga saat ini masih banyak belum disosialisasikan di masyarakat secara menyeluruh. Sehingga ide-ide yang dicetuskan masih dalam tahap berita dan himbauan. Langkah nyata harus segera dilakukan, minimal memberikan pengenalan konsep- konsep ekonomi syariah utnuk berbisnis utamanya terkait dengan produk dan jasa yang diperbolehkan dan harus dihindari. Agar tujuan tujuan hidup masyarakat muslim penuh keberkahan dapat diwujudkan. Membangun Kesejahteraan masyarakat menjadi kehendak bersama, sehingga peyelesaian terhadap pemberdayaan masyarakat juga harus dipikirkan bersama khususnya dalam system keuangan syariah. Berusaha dalam bentuk yang dihalalkan oleh agama menjadi ide penting 
baru kemudian memahami tata cara pengaturan keuangan berdasarkan tuntunan syariat yang sudah jelas ditawarkan. Menurut Hasyim Azhari Support Officer PT

Zahir Internasional bahwa bagi para generasi muslim yang akan membangun usaha atau berwira usaha dengan menerapkan prinsip Syariah akan diperoleh berbagai kemanfaat antara lain:

1. Di dalam bisnis banyak pengalaman akan diperoleh baik di segi manajemen, mengenal tempat, mengenal barang dan lain-lain lagi. Di dalam Islam mencari ilmu dan pengalaman sangat dituntut.

2. Keberlangsungan. Target yang telah dicapai dengan pertumbuhan setiap tahunnya harus dijaga keberlangsungannya agar perusahaan dapat exis dalam kurun waktu yang lama.

3. Keberkahan. Semua tujuan yang telah tercapai tidak akan berarti apa-apa jika tidak ada keberkahan di dalamnya. Maka bisnis Islam menempatkan berkah sebagai tujuan inti, karena ia merupakan bentuk dari diterimanya segala aktivitas manusia. Keberkahan ini menjadi bukti bahwa bisnis yang dilakukan oleh pengusaha muslim telah mendapat rida dari Allah Subhanahu wa Ta'ala dan bernilai ibadah.

4. Pertumbuhan. Jika profit materi dan profit non materi telah diraih, perusahaan harus berupaya menjaga pertumbuhan agar selalu meningkat. Upaya peningkatan ini juga harus selalu dalam koridor syariah, bukan menghalalkan segala cara.

5. Target hasil: profit-materi dan benefitnonmateri. Artinya bahwa bisnis tidak hanya untuk mencari profit (qimah madiyah atau nilai materi) setinggitingginya, tetapi juga harus dapat memperoleh dan memberikan benefit (keuntungan atau manfaat) nonmateri kepada internal organisasi perusahaan dan eksternal (lingkungan), seperti terciptanya suasana persaudaraan, kepedulian sosial dan sebagainya.

6. Benefit. Yang dimaksudkan tidaklah semata memberikan manfaat kebendaan, tetapi juga dapat bersifat nonmateri. Islam memandang bahwa tujuan suatu amal perbuatan tidak hanya berorientasi pada keuntungan semata. Masih ada tiga orientasi lainnya, yakni bantuan sosial (sedekah), dan bantuan lainnya.

7. Pengelola berusaha memberikan manfaat yang bersifat kemanusiaan melalui kesempatan kerja, bantuan sosial (sedekah), dan bantuan lainnya.

8. Nilai-nilai akhlak mulia menjadi suatu keharusan yang harus muncul dalam setiap aktivitas bisnis sehingga tercipta hubungan persaudaraan yang Islami, bukan sekadar hubungan fungsional atau profesional.

9. Aktivitas dijadikan sebagai media untuk mendekatkan diri kepada Allah Subhanahu wa Ta'ala.

\subsection{Permasalahan Mitra}

Berdasarkan kajian situasi obyek PkM diperoleh beberapa permasalahan:

a. Sebagai masyarakat muslim dan Muslimah banyak yang masih belum mengenal tata bisnis secara syariah. Akibatnya dalam melakukan usaha mencari sumber keidupan masih saja beberapa larangan agama masih dijalankan. Hal ini tidak lepas bahwa masyarakat Indonesia yang menerima Islam dalam bentuk budaya. Sehingga ilmu keislaman kurang banyak dipahami dan diamalkan. Mereka hanya mengamalkan ibadah harian yang diajarkan oleh orang tua bahkan para guru mengaji di kampungnya. Literasi keagamaan tidak banyak dikaji paling tidak mereka diajarkan tentang halal haram yang tidak menyentuh sisi dalam yang mendasar. Tidak menjadi aneh kemudian masyarakat masyarakat kadang tahu itu tidak boleh dikerjakan namun karena tuntutan sumber kehidupan bayak dilalaikan tetrutama kertika mengambil alas an banyak orang juga melakukan. Hal ini juga yang menjadikan konsep ekonomi islam sedikit bergerak lambat pekembangannya.

b. Belum intensifnya pembelajaran tuntunan bisnis dalam islam. Ini dapat dilihat baik pada lembaga formal maupun informal belum banyak dikaji tentang tata cara bisnis terutaha dalam 
hal transaksi yang diajarkan dalam islam. Majlis -majlis ilmu baik melalui masjid maupun kelompok-kelompok pengajian umumnya pembelajaran masih membahas pada sisi ibadah mahdhah. Pembahasan tata cara bermuamalah dalam bentuk usaha keseharian tidak banyak dibahas. Sehingga dirasa tidak penting bahkan ada pemahaman bahwa berbisnis dan beragama adalah dua hal berbeda. Beragama untuk akhirat sementara seakan kedunian tidak ada kaitannya.

c. Kengganan masyarakat untuk berubah. Ada stigma bahwa bisnis secara syariah tidak menguntungkan. Stigma ini timbul karena pengaruh budaya ekonomi konvensional dengan basis riba dan menghalalkan segala cara. Mengurangi timbangan, bisnis kotor, suap-menyuap, saling memeras, tidak mau rugi, tidak mau berbagi berpinsip memperoleh dan mengambil sebanyak-banyaknya menjadi prinsip yang sudah mandarah daging. Jika mau sadar inilah yang tidak menimbulkan keberkahan dalam hidup. Kesejahteraan tak terasakan karena system konvensional yang tidak mengenalkan kesejahteraan bersama. Prinsipnya kaya untuk pribadi dan sekelompok orang. Orang miskin dinaggap nasib siapa yang kuat mereka dapat, berbagai adalah tabu. Padahal kebutuhan untuk hidup layak adalah kemauan semua orang. Orang yang diberi lebih dari yang lain semestinya menjadi agen-agen kesejahteraan bagi rang lain.

\section{TARGET DAN LUARAN}

\subsection{Target}

Khalayak sasaran pada legiatan PkM adalah ibu-ibu anggota Majlis Ta'lim An-Nisa Jalan Bakung 04 Kelurahan Lowokwaru Kota Malang. Target yang diharapkan pada kegiatan PkM ini adalah bahwa permasalahan yang dihadapai ummat Islam di Indonesia setahap demi setahap terselesaikan dengan mulai dari yang masih lingkup kecil dan sederhana.
Mencermati beberapa permasalahan yang dihadapai, maka target yang diharapkan adalah:

a. Audien yakni Ibu-ibu anggota majlis ta'lim memehamai secara benar tentang konsep usaha dan transaksi-transaksi bisnis berbasis syariah.

b. Peserta kegiatan diberikan arahan dan motivasi untuk mencermati setiap kegiatan usaha menerapkan kaidahkaidah syariah yang benar.

c. Bagi peserta yang telah memiliki usaha atau akan membangun kegiatan bisnis dapat melakukan konsultasi tentang praktik transaksi syariah.

d. Bagi yang memiliki modal menganggur diharapkan berniat untuk merencanakan praktik syirkah untuk pemberdayaan kaum muda yang masih memerlukan jembatan perolehan rizki.

e. Bagi pemodal yang sudah terlanjur menabung di perbankan konvensional perlu segera mempertimbangkan penghindaran riba dengan mencari alternatif investasi yang lebih menyelamatkan dan menjanjikan.

f. Jika dimungkinkan dibentuk lembaga semi informal dalam bentuk koperasi syariah untuk melayani kebutuhan antar anggota agar semangat tolong menolong untuk ketaqwaan teewujudkan.

g. Keberlanjutan kegiatan $\mathrm{PkM}$ dengan pengembangan topik yang lebih praktis di masa mendatang.

h. Mengembangkan kegiatan untuk khalayak yang lebih meluas minimal satu kecamatan Lowokwaru melalui kegiatan majlis ta' 1 lim.

i. Kerjasama dengan Tim PkM lain di POLINEMA untuk memberikan pelatihan kewirausahaan bidang- bidang bisnis yang aktual baik bisnis produksi barang maupaun pelayanan bentuk jasa.

\subsection{Luaran}

Luaran kegiatan ini adalah:

a. Laporan untuk lembaga sesuai dengan konsep yang sudah ditentukan

b. Publikasi lewat Jurnal ADBIS Jurusan Adinistrasi Niaga POLINEMA

c. Luaran untuk obyek atau mitra berupa pembuatan buku saku yang berisi tentang kaidah-kaidah praktis transaksi 
syariah dan syarat-syarat sahnya syariat, bentuk akad syariah, konsep uang, konsep kerugian, konsep nisbah dan contoh-contoh praktis dalam dunia bisnis yang sudah berjalan.

d. Membangun jaringan dengan pihak perbankan yang sudah berbasis syariah terkait dengan kebutuhan pendanaan masyarakat untuk pengembangan bisnis.

\section{METODE}

\subsection{Khalayak Sasaran dan Lokasi Kegiatan}

Sasaran peserta pada pengabdian masyarakat ini adalah ibu-ibu pengajian An Nisa Jalan Bakung No. 4 Kota Kelurahan Lowokwaru, Kecamatan Lowokwaru Kota Malang. Anggota berjumlah kurang lebh 46 orang. Pada kegiatan kali ini karena adanya kendala pademi maka pelaksanaan dilaksanakan di Masjid Fadhilah Jln. Mawar 97 Kota Malang. Waktunyapun berubah menjadi setelah berjamaah subuh yakni jam 05.00 hingga jam 07.00 WIB setiap hari Selsa selama du kali tatap muka. Yakni Selasa 18 dan 25 Agustus 2020.

\subsection{Metode PKM}

Kerangka pemecahan masalah :

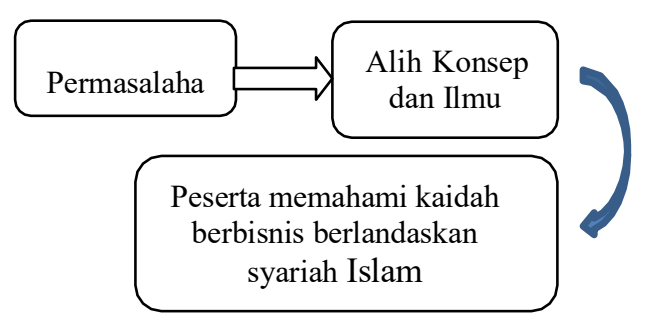

Teknik pemecahan masalah yang ditawarkan melalui kegiatan ini diarahkan pada pembelajaran dengan dasar :

- Memahami dengan cermat permasalahan yang sedang terjadi serta memberikan kesadaran tentang kemanfaatan praktik bisnis dengan konsep basis syariah.

- Memberikan penjelasan melalui beberapa contoh latihan tentang penerapan transaksi usaha secara syariah terkait dengan bidang Syariah.

Metode pelaksaanaan yang ditawarkan adalah tatap muka dengan cara:
Teknik pemecahan masalah yang ditawarkan melalui kegiatan ini diarahkan pada pembelajaran dengan dasar:

- Memahami dengan cermat permasalahan yang sedang terjadi serta memberikan kesadaran tentang kemanfaatan praktik bisnis dengan konsep basis syariah.

- Memberikan penjelasan melalui beberapa contoh latihan tentang penerapan transaksi usaha secara syariah terkait dengan bidang Syariah.

Metode pelaksaanaan yang ditawarkan adalah tatap muka dengan cara:

\section{a. PENYULUHAN}

Penyuluhan adalah bentuk usaha pendidikan non- formal kepada individu atau kelompok masyarakat yang dilakukan secara sistematik, terencana dan terarah dalam usaha perubahan perilaku yang berkelanjutan demi tercapainya peningkatan produksi, pendapatan dan perbaikan kesejahteraan (Riadi, 2020).

Adapun tujuan penyuluhan, yaitu tujuan jangka pendek dan tujuan jangka panjang, antara lain (Kartasaputra,1987):

a. Tujuan Jangka Pendek

1. Perubahan tingkat pengetahuan.

2. Perubahan tingkat kecakapan atau kemampuan.

3. Perubahan sikap.

4. Perubahan motif tindakan.

b. Tujuan Jangka Panjang

1. Better farming, mau dan mampu mengubah cara-cara usaha dengan cara-cara yang lebih baik.

2. Better business, berusaha yang lebih menguntungkan.

3. Better living, menghemat dan tidak berfoya foya setelah tujuan utama telah tercapai.

Menurut Maulana (2009), secara umum terdapat beberapa faktor yang mempengaruhi proses perubahan keadaan yang disebabkan karena penyuluhan, yaitu:

1. Keadaan pribadi sasaran. Beberapa hal yang perlu diamati pada diri sasaran penyuluhan adalah ada tidaknya motivasi pribadi sasaran penyuluhan dalam melakukan suatu perubahan. Berikutnya, adanya ketakutan atau trauma di masa lampau yang berupa ketidakpercayaan pada pihak lain karena pengalaman 
ketidak-berhasilan atau kegagalan, kekurangsiapan dalam melakukan perubahan karena keterbatasan pengetahuan, keterampilan dana, saran, dan pengalaman serta adanya perasaan puas dengan kondisi yang dirasakan sekarang tanpa harus melakukan perubahan.

2. Keadaan lingkungan fisik. Lingkungan fisik dalam hal ini adalah lingkungan yang berpengaruh baik secara langsung maupun tidak langsung dalam keberhasilan penyuluhan.

3. Keadaan sosial dan budaya masyarakat. Sebagai pola perilaku sudah sewajarnya apabila kondisi sosial budaya di masyarakat akan mempengaruhi efektivitas penyuluhan karena kondisi sosial budaya merupakan suatu pola perilaku yang dipelajari, dipegang teguh oleh setiap warga masyarakat dan diteruskan secara turun-temurun dan akan sangat sulit merubah perilaku masyarakat jika sudah berbenturan dengan keadaan sosial budaya masyarakat.

4. Keadaan dan macam aktivitas. Kelembagaan yang tersedia dan Menunjang Kegiatan Penyuluhan. Ada tidaknya peran serta terkait dalam proses penyuluhan akan menentukan efektivitas penyuluhan. Dalam hal ini lembaga berfungsi sebagai pembuat keputusan yang akan ditetapkan sehingga harus dilaksanakan oleh masyarakat.

5. Ketersediaan waktu di masyarakat. Waktu penyampaian informasi harus memperhatikan tingkat aktivitas masyarakat untuk menjamin tingkat kehadiran masyarakat dalam penyuluhan Penyuluhan merupakan cara yang paling tepat dalam memberikan pengetahuan kepada masyarakat untuk memantapkan pelaksanaan kegiatan dan hasil penyuluhan. Pada kegiatan ini jenis-jenis transaksi usaha secara Syariah dirangkum melelui sajian presentasi melalui Power Point dan penjelasanpenjelasan secara ringkas sesuai denga nisi materinya. Pada sajian presentasi juga diberikan beberapa topik diskusi yang terkait dengan pengalaman keseharian peserta kemudian dikaji keabsahannya semnurut kaidah Syariah Islam.

\section{b. DEMONSTRASI, PELATIHAN, DAN BIMBINGAN}

Disamping pemberian materi tentang transaksi bisnis, akad-akad dan produk syariah, dalam pelatihan ini juga memperagakan dan mempercontohkan cara mekanisme perhitungan bagi hasil yang meliputi metode perhitungan bagi hasil, tahapan perhitungan bagi hasil, faktor penentu bagi hasil serta contoh- contoh kasus perhitungan bagi hasil dan profit margin perbankan syariah Diskusi dan Konsultasi. Pada saat sosialisasi/pelatihan dan bimbingan disertai dengan diskusi dan konsultasi untuk lebih memantapkan kegiatan pengabdian kepada masyarakat yang dilaksanakan.

Mempertimbagkan protocol kesehatan, pelatihannya tidak dapat berjalan maksimal. Peserta hanya dapat memberikan beberapa pertanyaan terkait dengan contohcontoh yang disajikan lembar kerja soal dan kasus-kasus tidak bisa dikerjakan. Namun melalui tayangan yang disajikan peserta sudah cukup memperoleh gambaran tentang tata cara akad dan bentuk-bentuk transaksi yang harus di praktikkan dalam keseharian.

Untuk kegiatan bimbingan tim memberikan arahan bahwa setiap waktu peserta dapat menguhubungi tim $\mathrm{PkM}$ bila perlu arahan dan pertimbangan melalui tilpun dan WhatsApp.

\subsection{Rancangan Evaluasi}

1. Evaluasi Sebelum Kegiatan

Sebelum melaksanakan kegiatan dilakukan observasi pendahuluan, membuat persiapan materi dan media, agar kedua hal yang telah dirancang bisa diterima oleh peserta.

2. Evaluasi Selama Kegiatan Selama melakukan kegiatan, dilakukan evaluasi sebagai berikut:

a. Evaluasi terhadap kehadiran peserta dan kesiapan tempat serta ketersediaan bahan-bahan ajar, fasilitas dan tata ruang

b. Evaluasi hambatan baik masalah penyampaian materi maupun hal-hal yang bersifat teknis.

c. Evaluasi kelayakan materi yang diberikan.

d. Evaluasi daya penerimaan materi peserta/ penyerapan materi. 
3. Evaluasi terhadap kemampuan para peserta.

4. Evaluasi akhir kegiatan

\section{KELAYAKAN PENGUSUL DAN MITRA}

\section{Kelayakan Pengusul}

Kegiatan pengabdian kepada masyarakat ini akan dilaksanakan oleh tim dengan jumlah personal 4 orang. Kompetensi dan pembagian tugas tim pengusul dapat dijelaskan. Keahlian yang diimiliki : Keuangan dan Akuntansi, Kebijakan Bisnis, Akuntansi emerintahan dan Akuntansi Keuangan. Pembagian waktu masing- masing kisaran 10-15 jam perminggu. Untuk persiapan dan pelaksanaan PkM tim telah melakukan pembagian tugas dengan porsi dan kondisi masing-masing.

\section{Kelayakan Mitra}

Berdasarkan pengamatan pendahuluan anggota Ibu-ibu majlis ta'lim An Nisa mempunyai latar belakang yang cupup potensial. Rata-rata berpendidikan cukup bahkan sebagian lulusan peguruan tinggi diploma dan sarjana. Sehingga sangat berpotensi untuk mengembangkan diri dalam menerima sosialiasi dan implementasi materi kaidah bisnis secara syariah. Selain latar pendidikan yang cukup secara ekonomi anggota pengajian ini cukup mapan karena selain mereka bersuami pegawai mereka juga sebagian mempunyai usaha dagang atau jasa yang cukup sukses.

Usia anggota majlis ta'lim ini bervariasi ada yang masih 3 tahun ada juga sudah 50 tahun. Hal yang menggembirakan semangat untuk mengikuti kajian keilmuan khususnya dibidang keagamaan sangat dibanggakan. Merekan melakukan pengajin seulan dua kali. Menurut ketua majlis bahwa jamlah mereka beriksar 40 sampai 60 orang, dan yang pasti selalu hadir antara 40 dampai 50 orang. Maka Ketika ketua tim PkM mengajukan tawaran untuk kegiatan pengabdian kepada masyarakat mereka sangat antusias dan bersemangat. Kondisi ini cukuplah menjadi bekal bahwa kegiatan akan berjalan dengan baik

Kelayakan obyek PkM ini juga didukung oleh tingkat kebersamaan diantara para anggota yang cukup solid. Melalui kebersamaan dalam jamaah telah diwujudkan oleh kepedulian antar anggota untuk saling membantu dalam berbagai hal yang terkait dengan pinsip kebersamaan untuk sejahtera. Sesuai dengan kaidah bisnis secara syariah bahwa kebersamaan dalam kemakmuran adalah impian yang perlu diwujudkan. Kekayaan bukan untuk dimiliki sendiri namun seharusnya diperankan untuk menciptakan kebahagian bersama di masyarakat. Melalui kegiatan ini diharapkan pemahaman terhadap bisnis secara semakin mendalam sehingga berdampak bagi yang sudah mempunyai usaha mampu menimbulkan anggota lain atau masyarakat dimana mereka berada untuk memulai rintisan usaha. Mengingat bahwa kesempatan berbisns halal sangat terbuka luas. Sehingga dengan memahami dan semangat menerapkan dalam keseharian timbul semangat yang bermodal membantu dan membimbing dalam perintisan usaha dan pengelolaannya.

\section{HASIL DAN PEMBAHASAN}

\section{Hasil Pelaksanaan PKM}

Kegiatan PKM ini berbentuk pelatihan dan pemberian wawasan kepada peserta. Peserta kegiatan berjumlah 46 orang peserta terdiri dari bapak/ibu. Pelaksanaan pada hari Selasa 18 dan 25 Agustus 2020 pukul 5.00 07.00. Rencana semula obyek kegitan ini adalah Majlis Ta'lim An-Nisa namun seiring adanya pendemi maka pelaksanaan diadakan di Masjid Fadhilah Jalan Mawar 50 Kota Malang. Hasil kegiatan ini diharapkan bahwa para peserta memperoleh pemahaman (kognisi) atas transaksi bisnis Syariah dan produk- produknya yang semestinya dilakukan dalam dunia bisnis berdasarkan syariah. Hal ini dipentingkan mengingat sebagai orang mukmin yang bertakwa dituntut untuk menjadi manusia yang betakwa sebenar- benar dan menjadi seorang muslim yang yang dalam beragama dituntut untuk masuk secara keseluruhan atau kaffah.

Seperti harapan dari kegiatan ini, bahwa pelaksanaan dinilai cukup berhasil dengan banyaknya jumlah perserta yang mengikuti kegiatan ini. Selama kegiatan berlangsung animo cukup baik dengan berbagai pertanyaan yang diajukan. Ada beberapa peserta yang dahulunya pegawai 
bank konvensional. Mereka baru mendapatkan informasi tentang bahayanya ghoror dan riba dalam dalam menciptakan kesulitan dalam masyarakat. Peserta mengambil contoh tentang tingginya kredit macet di Indonesia. Dalam istilah perbankan kredit macet juga disebut dengan Kredit Bermasalah/ Non Performing Loan (NPL). Kredit macet timbul dapat disebebakan oleh beberapa hal antara lain adanya kondisi alam indoneaia yang sering menciptakan ancaman dalam kegiatan bisnis semisal gempa yang terjadi di beberapa wilayah Indonesia. Artinya tidak semua kredit macet akibat wanprestasi secara sengaja dalam bentuk penipuan. Hal demikian memang harus ditertibkan berdasarkaan hukum, namun pada situasi karena risiko yang tidak terkendali semetinyalah menjadi perhatian. Pada sisi lain kemungkinan timbulnya kredit karena akad atau perjanjian yang tidak adil. Pemilik modal (perbankan) lebih memberikan tekanan melalui keuntungan dalam bentuk bunga yang sudah di tetapkan yang nilainya kadangkala lebih besar dari tingkat keuntungan yang digharapkan nasabahnya. Sehingga memberatkan bagi para pengusaha utamanya Usaha Mikro di pedesaan.

Bagi dunia perbankan, sebuah kredit yang tergolong dalam bermasalah (NPL/non performing loan) akan memberikan dampak bagi kinerja bank. Bank butuh waktu dan cara tersendiri untuk mengembalikan kondisi agar kembali dalam kondisi normal lagi. Kredit NPL yang diakibatkan bencana alam dalam jumlah besar, apalagi terjadi Bagi dunia perbankan, sebuah kredit yang tergolong dalam bermasalah (NPL/non performing loan) akan memberikan dampak bagi kinekeja bank. Kredit NPL yang diakibatkan bencana alam dalam jumlah besar, apalagi belajar dari kebijakan dan keputusan yang pernah diterapkan oleh pemerintah sebagai pemegang policy, antara satu kasus dengan kasus lain terlihat ambigu dikarenakan pemerintah memberikan dan menerapkan keputusan yang berbeda-beda.

Beberapa kebijakan tentang kredit bermasalah yang diberikan oleh pihak otoritas perbankan kepada para nasabah antara korban banjir di Manado dan erupsi Gunung Sinabung di Karo dengan kebijakan korban letusan Gunung Merapi di Jawa Tengah (Adlan,
2016). Perbedaan penerapan kebijakan tersebut tentu dirasa membingungkan dan menimbulksn rasa tidak adil bagi sebagian nasabah korban bencana alam, utamanya bagi pengusaha UMKM, di mana keputusan yang mereka terima kurang berpihak kepada mereka. Seakan-akan negara terlalu berpihak kepada para pemegang dan pemilik modal saja. Dalam kasus bencana erupsi Gunung Kelud, OJK telah memberikan keputusan dengan diberikannya kebijakan keringanan hutang berupa restrukturisasi/relaksasi hutang dalan jangka waktu 3 tahun kepada para nasabah/debitur melalui penjadwalan angsuran, keringan bunga hingga pemberian kredit tambahan untuk mempercepat pemulihan debitor yang usahanya dinilai bagus, bukan penghapusan hutang sebagaimana yang pernah diterapkan bagi debitur usaha kecil dan menegah (UMKM) korban erupsi Gunung Merapi meskipun keputusan ini diraih melalui proses mediasi dan gugatan selama 7 tahun. Keputusan tentang restrukturisasi/ relaksasi hutang bagi debitur bencana Gunung Kelud ini juga dibarengi dengan embel-embel syarat agar para debitur segera mengajukan permohonan restrukturisasi kreditnya selambat-lambatnya 3 bulan

terhitung sejak keputusan itu dikeluarkan agar mereka tidak dimasukan ke dalam kategori debitor bermasalah. Sebuah kebijakan yang sama dan pernah diterapkan bagi debitur korban banjir di Manado dan erupsi Gunung Sinabung di Karo.

Seharusnya, dalam kasus kredit macet akibat bencana letusan gunung berapi dikategorikan ke dalam kredit macet yang disebabkan kondisi force majeure, sebagai unsur ketidaksengajaan yang diartikan debitur mau membayar tetapi tidak mampu dikarenakan sebab dari luar kendalinya Setidaknya terdapat 3 alasan yang dapat di kategorikan sebagai force majeure, (1) tidak dipenuhinya prestasi karena terjadi peristiwa membinasakan atau memusnahkan benda objek perikatan; (2) ada sebab yang terletak di luar kesalahan debitur karena terjadi peristiwa yang menghalangi perbuatan debitur untuk berprestasi; (3) faktor penyebab itu tidak dapat diduga sebelumnya dan tidak dapat dipertanggungjawabkan kepada debitur. Konsekuensi hukum yang timbul semestinyan 
dikategorikan sebagai keadaan memaksa (force majeure) ini adalah: (1) kreditur tidak dapat menuntut pemenuhan prestasi; (2) debitur tidak dapat lagi dinyatakan lalai; (3) debitur tidak wajib membayar ganti rugi; (4) kreditur tidak dapat menuntut pembatalan dalam perjanjian timbal balik; dan (5) perikatan dianggap gugur.

Menurut perspektif Islam, hukum Islam diciptakan dan dilaksanakan secara menyeluruh tidak lain adalah bertujuan demi kemaslahatan dan kesejahteraan manisia di dunia dan akhirat. Untuk mencapai tujuan tersebut maka hukum Islam mempunyai beberapa prinsip yang mendasari terlaksananya tujuan tersebut, yaitu: 1) memberikan kemudahan dan meniadakan kesulitan, 2) menyedikitkan beban, dan 3) menempuh jalan pertahapan. Asas kemaslahatan baik perorangan maupun masyarakat dalam urusan muamalah adalah asas yang paling pokok dalam pembinaan fiqh oleh sebab itu hukum harus berkisar dari illatnya. Selain itu, maksud diturunkan hukum tahap demi tahap adalah agar seiring dengan kemaslahatan manusia itu sendiri. Pada praktek kegiatan ekonomi, masyarakat muslim harus memperhatikan prinsip-prinsip perekonomian Islam, demi menjaga kemaslahatan bersama dengan memegangi prinsip-prinsip: 1) pada dasarnya segala bentuk muamalah adalah mubah, kecuali yang ditentukan lain oleh nash (al-Qur'an dan Sunnah); 2) mu'amalah harus dilakukan atas dasar pertimbangan mendatangkan manfaat dan menghindarkan madharat dalam hidup manusia; 3) muamalah dilakukan atas dasar sukarela tanpa mengandung unsur paksaan; dan 4) muamalah dilakukan dengan memelihara nilai-nilai keadilan, menghindari unsur-unsur penganiayaan dan tidak adanya usaha untuk mencari-cari kesempatan dalam kesempitan orang lain

\section{Relevansi}

Majelis ini didirikan karena motivasi dari Ibu-ibu Pengajian Annisa Jln Bakung 04 Lowokwaru Malang. untuk lebih dalam memehami praktek transaksi Syariah dalamm kehidupan sehari-hari. Kajian yang terkait dengan produk syariah sebenarnya tercakup dalam kajian fiqh namun sepertinya yang sedang terjadi di masyarakat Indonesia kajian terkait dengan ekonomi dan bisnis

syariah masih banyak belum dilakukan. Sehingga sebagian kaum muslimin banyak yang belum mengenal dan bahkan sebagain berprasangka seakan urusan berdagang dan bisnis tidak diatur oleh agama. Mereka muslim tapi banyak berdagang barang syubhat bahkan haram atau dengan cara-cara yang dianggap benar secara akal perhitungan bisnis. Padahal sebagai seorang muslim kehati-hatian dalam mengais rizki adalah hal yang menjadi perhatian penting dalam hidup. Pemeliharaan agama adalah salah satu doa yang diajarkna Nabi. Yakni yang berbunyi : Ya Allah perbaikilah agamaku yang dengan agama itu menjadi pentingnya urusanku (al hadist).

Tujuan hidup kaum kau muslimin selalu diarahkan menuju kebahagiaan dunia dan akhirat. Untuk mencapainya Islam menyajikan syariat yang berupa aturan hukum yang harus diikuti. Hidup manusia adalah ujian. Dihadapkannya berbagai kemugkinan pilihan menjadikan setiap jiwa manusia harus mampu menggnakan daya hidup dan daya nalr serta daya hati untuk memutuskan sebuah perilaku yang dinilai benar. Karena nilai kebenaran inilah yang kan menghantar kannya menuju tujuan mulianya. Oleh karenanya pemahaman dan kesadaran terhadap amaliyah islamiyah keseharian adalah mutlak. Jaminan tentang keselamatan dunia dan akhirat hanya akan diperoleh jika setiap pribadi muslim teguh dengan pengamalan ajarannya.

\section{Efektifitas}

Secara keseluruhan pelaksanaan PKM ini berjalan lancar. Efektifitas penggunaan waktu telah di rencanakan dengan baik. Mengingat kelas pembelajaran bersifat informal sehingga pendekatan secara informal melalui pihak yang yang terkait harus dilakukan secara intensif.

Beberapa kendala banyak terkait dengan pandemi yang sedang berlangsung. Pengaturan jadwalmtatap uka menjadi pmasalah karena msyarakat harus mengikuti aturan pertemuan dalam jumlah banyak. Karena jumlah peserta sekitar 40 orang, maka tempat yang biasanya untuk pertemuan pengajian menjadi tidak layak untuk ditempati. Selain itu kendala berikutnya adalah kegiatan 
sementara diliburkan karena sebagian anggota majelis pengajian ibu-ibu yang sudah berumur. Pada akhirnya setelah masjid-masjid mulai mengadakan kegiatan berjamaah termasjik masjid Fadhilah di jalan Mawar yang lokasinya berdekatan dengan lokasi pengajian Manjlis An-Nisa, tim mengadakan pendekatan untuk mengadapat kegiatan $\mathrm{PkM}$ bersamaan dengan kegiatan jamaah sholat subuh. Setelah ada kesepakatan antara takmir masjid dan ibubu anggota pengajian maka pelaksanaannya dijadwalkan hari Selasa tanggal 18 dan 25 Agustus 2020. Pada akhirnya pelaksanaan berjalan sesuai dengan rencana. Tim dapat memberikan materi PkM sesuai dengan yang diharapkan.

\section{Kemanfaatan}

Melemahnya peran ekonomi kapitalis dan sosialis menjadikan para pakar ekonomi harus mencari alternatif sistem ekonomi yang elegan dan mampu menciptakan kesejahteraan dengan kedamaian. Bukti terjadinya penguasaan sepihak khususnya para pemodal yang kuat dalam sistem berekonomi konvensional memberikan pengalaman yang kurang diharapkan. Penguasaan asset negara pada segelintir orang menjadikan sebagain besar masyarakat dalam suatu komunitas dikorbankan. Ketertindasan bagian terbesar dari komunitas memberikan dampak buruk dalam kehidupan dalam bentuk sikap hidup dengan mengandalkan kekerasan sehingga megambil bagian dengan cara paksa bahkan cara yang asusila dengan tanpa memperhatikan hak hidup sesama. Kondisi inilah yang memotivasi kesadaran untuk hidup lebih manusiawi, wajar dan mengedepankan keadilan antar sesama agar kesejahteraan bersama tercapai. Ekonomi berdasarkan syariat islam merupakan pilihan yang harus di terapkan agar semua harapan kehidupan terwujudkan.

Jika masyarakat dunia yang bahkan non muslim mulai banyak belajar tentang sistem keuangan syariah maka betapa naifnya masyarakat islam sendiri yang mempunyai ajaran mulia ini justru belum dan bahkan tidak mengenalnya. Manfaat kegiatan PkM ini diarahkan bahwa bergerak dari yang kecil untuk menuju yang lebih bsar dengan cara sgera untuk dimulai. Langkah nyata yang harus didukung dan diwujudkan. Penciptaan kesejahteraan masyarakat harus dilakukan oleh masyarakat sendiri, tentunya dengan peran yang berbeda sesuai dengan kontribusi yang dapat disumbangkan dengan bingkai kesejahteraan bersama.

Temuan dari kegiatan PkM ini bahwa selama penyampaian materi peserta sangat antusias. Penjelasan mengenai praktek transaksi syariah masih belim nanyak dipahami secara jelas. Mereka memang mengenal tentang istilah riba namun bagaimana praktik riba terjadi masih banyak penjelasan. Termasuk pengertian ghoror atau penipuan dalam islam yang dilarang yang justru dipraktikkan oleh masyarakat. Contoh tentang penipuan dalam timbangan. Masyarakat mempunyai pemahaman bahwa denan mengurangi timbangan dan takaran dianggap sebagai cara untuk memperoleh keuntungan. Pinjam meminjam dengan gaya rentenir karena kebutuhan mendesak yang justru menciptakan kesulitan di kemudian hari. Hal-hal demikian haraus terus dijelaskan agar masyarakat berubah. Pembiaran akan mengakibatkan kebodohan yang akan menimbilkan penyelasan.bayak Berbagai pertanyaan diajukan terkait dengan evaluasi diri tentang yang selama ini telah dilakukan. Antusias peserta terhadap topik ini mengindikasi bahwa mereka sudah mulai ada kesadaran untuk membangun kehidupan dengan nilai syariah.

Setelah diajelaskan tentang bahaya riba dan bisnis dengan cara penipuan serta beberapa ancaman dalam Al-Qur'an banyak peserta yang mulai memperoleh kesadara melalui berbagai penyampaian kasus pribadi atau pengamatan yanag mereka lakukan. Mereka cukup dikagetkan dengan berbagai kenyataan bahayanya konsep bisnis yang tak mindahkan syariah sebagai orang Islam. Dampak buruk riba yang kadang tidak mereka rasakan di dunia sekan memakan riba sudah biasa. Padahal ancaman pelaku riba sangat keras kelak dihari pembalasan. Limpahan rizki secara finansial di dunia dirasakan semu. Kurang pemahaman atau kurangnya kepedulian terhadap konsep riba menjadikan mereka para pemakan riba tidak sadar sedang berkubang dalam ketikbenaran. Makanan yang dikais melalaui jalan haram kemudian masuk dalam perut kemudian menjadi darah yang mengalir dalam menjadikan hati manusia 
semakin keras dan legam. Gelapnya hati tersebut menjadikan hilangnya kelembutan rasa dalam mencermati akibat melanggar larangan agama. Mereka atau kita adalah umat islam tetapi mudah mengabaikan kemaksiatan. Seakan apa yang dilakukan tidak memberikan dampak dalam kehidupan. Gambaran inilah yang dalam agamag disebut tertipu (maghrur). Maknanya seorang yang sudah melakukan dosa dan akibat dosanya masih ditunda balasannya mereka berpikir bahwa tidak ada akibat yang dirasakan. Padalah Allah sedang menutup aib atas kesalahannya smengtara si hamba merasa terlindungi maka terus sajalah pebuatan itu dilakukan. Namun hendaknya diperhatikan bahwa kemaksiatan ada batasnya sampai saat tertentu pasti akibat kemaksiatan akan ditamapakkan balasannya.

Temuan-temuan ini diharapkan menjadi fase membangun kesadaran tentang menjadi umat islam yang kaffah. Tidak hanya tekun dalam ibadah kepada Allah (mahdhoh) tapi juga harus membangun muammalah yang lebih baik. Karena pada intinya islam justru ajaran banyak mengatur bagaimana mu'ammalah diamalkan dengan lebih masive. Islam adalah ajarah rahmat terciptanya kedamaian. Kedaaian bisa diciptakan jika masyarakat relatif telah pada taraf sejahtera dan ukuran sejahtera paling sederhana adalah kecukupan hidup dan ini pasti berbincang tentang jalan rizki serta ksejahteraan ekonomi. Masyarakat madani adalah masyarakat yang dibangun oleh Rasul Mulia, penopang utama adalah Iman berati mengenal tentang Pemilik Semesta kemudian Islam yang maknanya adalah syariat yang berisi aturan main tentang hubungan dengan Sang Khaliq dan hubungan hizontal antar kita sesam manusia dan lingkungannya dan yangh terkahir perilkau mulia yang disebut dengan Ihsan.

\section{SARAN}

\subsection{Simpulan}

Beberapa seimpulan yang dapat diambil pada kegiatan Pengabdian Kepada Masyarakat adalah:

1. Peserta pelatihan kegiatan PkM ini adalah jamaah Pengajian Ibu-Ibu An-Nisa Jalan Bakung 04 Kelurahan Kecamatan Lowokwar Kota Malang
2. Karena pertimbangan pandemi pelaksanaan dilakukan di Msjid Fadhilah Jalan Mawar Kelurahan Kecamatan Lowokwaru Kota Malang

3. Jumlah peserta sebanyak 46 orang terdiri dari wilayahsekitar lokasi masjidt.

4. Pelaksanaan kegiatan terlaksana sesuai dengan jadwal yang telah di kooordinasikan Hari Selasa 18 dan 25 Agustus 2020 pukul 05.00 s.d 07.00

5. Selama pelatihan peserta mengukuti dengan seksama serta berperan aktif dalam proses pembelajaran.

6. Kegiatan PKM ini merupakan lanjutan kegiatan sebelumnya diwilayah yang relatif berdekatan dengan peserta yang hampir sama dengan peserta pada PkM sebelumnya.

7. Antusiasme peserta mengindikasi ketertarikan peserta untuk memperoleh wawasan dan wacana tentang bisnis berbasis syariah Isalm. Adanya kesadaran perlunya sistem keuangan syariah diperkenalkan lebih intensif melalui berbagai media termasuk masjid sebagai tempat ibadah mauoun kominitas kegiatan islam dalam satu wikayah.

\subsection{Saran-saran}

Saran yang ddisampikan antara lain :

1. Kegiatan PKM perguruan tinggi bidangbidang alih wawasan khususnya terkait dengan wawasan sistem syariah perlu direncanakan secara terprogram dan simultan. Sehingga masing-masing perguruan tinggi teramsuk POLINEMA hendaknya menyediakan topik ini untuk disajikan kepada masyarakat melalui kegiatan PKM

2. Mengingat luasnya wilayah masyarakat yang akan dijadikan obyek PkM perencanaan terkait dengan obyek sasaran perlu ditata secara bertahap dan terarah lebih khusus di area Malang Raya.

3. Pelaksanaan PKM hendaknya dilaksanakan secara berlanjut agar pemahaman masyarakat semakin meningkat dan membuahkan kesadaran tentang pentingnya konsep keuangan syariah dalam membangun kemakmuran bersama.

4. Perlu diadakan komunitas binaan dengan membangun jaringan baik dengan 
lembaga pendidikan formal maupun non formal khususnya kelompok generasi muda.

5. Membangun kerjasama dengan perbankan syariah di wilayah Indonesia sehingga kegiatan bisnis masyarakat dapat dilakukan dengan memanfaatkan jasa perbankan syariah beserta sistem operasionalnya.

6. Untuk kegiatan PkM berikutnya akan lebih fokus dengan mengajak praktisi keuangan syaraih baik dari lembaga perbankan syaraih maupuan lembaga keuangan syariah yang lain agar penerapan sistem keuangan syariah bisa di jelaskan kepada masyarakat.

Kepada P2M Polinema perlu membuat program $\mathrm{PkM}$ dengan melibatkan grup PkM bidang teknis dan bidang manajemen khususnya bidang kewirausahaan untuk generasi muda melalui Karang Taruna atau lembaga pendidikan formal maupun informal denan semangat penerapam bisnis syariat Islam.

\section{DAFTAR PUSTAKA}

Al-Quran 2011, Tafsir Ibnu Katsir, Cetakan I, Alusindo, Bandung http://azharliqoh.blogspot.co.id/2010/02 /mengenal

-fiqih-muamalat-kontemporer.html

Ah. Azharuddin Lathif, M.Ag, Modul Mengenal Fiqh Muamalat

https://www.cnnindonesia.com/ekonomi/2020 $\underline{0804}$ 170438-78-532103/kredit-macetbank-sentuh-posisi- tertinggi-setahunterakhir

Dr. H. Nasrun Haroen, MA Fiqh Muamalah Jakarta: Gaya Media Pratama, 2007.

Hasan, 2009, Manajemen Bisnis Syariah, Cetakan ke I, Bina Ilmu, Yogyakarta Haroen, 2011, Makalah Fiqih Kontemporer

http://www.ekonomisyariah.org/tentanges/sejarah/http://dosenekonomi.com/ilm u- ekonomi/ekonomi-syariah/ekonomisyariah

Maulana, H. 2009. Promosi Kesehatan. Jakarta:

EGC

Novi, Keuangan Islam, UII Press Yogyakarta, 2002
Abu Muhammad, Hidup Berkah Tanpa Riba, Iluvia Publishing, Jakarta, 2018.

Ash-Shiddieqy, TM Hasbih, Pengantar Fiqh Muamalah, ed. 2, Semarang: Pustaka Rizki Putra, 1997

Pusat Pengkajian dan Pengembangan Ekonomi Islam (P3EI). 2012. Ekonomi Islam. Jakarta: PT Raja Grafindo Persada.

Zainuddin Ali. 2008. Hukum Ekonomi Syariah.

Jakarta: Sinar Grafika Offset. https://medium.com/@indotesis/pengert ian-tujuan-

prinsip-dan-manfaat-ekonomi-syariahd7412ace57a2 Muchlishin Riadi,

https://www.kajianpustaka.com/2020/01/peny uluhan- pengertian-tujuan-program.html

M. Aqim Adlan, 2016, Penyelesaian Kredit Macet Perbankan Dalam Pandangan Islam (Tinjauan Regulasi Kasus Kredit Macet Akibat Bencana Alam), Jurnal An Nisbah, Vol. 02, No. 02, April 2016

Kartasapoetra, AG. 1987. Teknologi Penyuluhan Pertanian. Jakarta: Bumi Aksara

https://pengusahamuslim.com/4590-manfaatbesar-berbisnis-yang-berpegang-padaprinsip- islam.html 